\title{
Translating the Metaphor: A Cognitive Stylistic Conceptualization (English - Arabic)
}

\author{
Hasan Said Ghazala ${ }^{1, *}$ \\ ${ }^{1}$ Department of English, Faculty of Social Sciences, Umm Al-Qura University, Makkah Al-Mukarramah, Saudi \\ Arabia \\ *Correspondence: Department of English, Faculty of Social Sciences, Umm Al-Qura University, Makkah \\ Al-Mukarramah, Saudi Arabia \\ E-mail: Ghazala@uqu.edu.sa
}

Received: November 22, 2012

Accepted: December 12, 2012

Online Published: December 15, 2012

doi:10.5430/wjel.v2n4p57

URL: http://dx.doi.org/10.5430/wjel.v2n4p57

\begin{abstract}
Metaphor is the key figure of rhetoric that usually implies a reference to figurative language in general. Therefore, it has always been attended to carefully by linguists, critics and writers. Traditionally, being originally a major aesthetic and rhetorical figure, it has been analysed and approached in terms of its constituent components (i.e. image, object, sense, etc.) and types (such as cliché, dead, anthropomorphic, recent, extended, compound, etc. metaphors). However, recently, and in the light of the latest developments of cognitive stylistics, metaphor has received yet greater attention from a completely different perspective of conceptualization and ideologization. Consequently, this change of perspective has its immediate effect on translation theory and practice, which has to be approached equally differently now with respect to translating metaphor.

This paper is an attempt to consider the translation of metaphor from a cognitive stylistic perspective, viewing it primarily as a matter of conceptualization of topics, objects and people. All metaphors are in principle reflections and constructions of concepts, attitudes, mentalities and ideologies on the part of the writer / speaker. Hence, any metaphor is conceptualized in terms of source domain and target domain in different texts, especially literary discourse. In translation, an instant positive response to this conceptualization of metaphor is anticipated by translators into the target language, on the basis of the two domains, the source and the target.

The conclusion aimed at by the paper is to turn focus to metaphor as a concretized, conceptualized, useful and updated cognitive figure of rhetoric both in theory and practice of translation. This will unearth yet unexplored dimensions of meaning, analysis, comprehension, interpretation, appreciation and translation of metaphor in both languages, the SL and the TL.
\end{abstract}

Keywords: metaphor; cognitive; target domain; source domain; conceptualization; translation; cognitive; stylistic perspective; conceptual; political metaphor; literary metaphor

\section{Introduction}

The translation of metaphor makes it necessary to start with investigating the concept of metaphor, past and present, with focus being on contemporary conceptual approaches to metaphor. There has been in recent years rapid and revolutionary changes not only in communications, computer and Internet technologies, but also, and surprisingly, in conceptual studies of metaphor. Metaphor is the process of 'transporting' qualities from one object to another, a person to another, a thing to a person or animal, etc. A metaphor was originally a Greek word for 'transport'. Understanding a metaphor as a sort of transport implies that it transports a concept from its normal location, to somewhere else where it is not usually used. Traditionally, metaphor was defined in aesthetic and rhetorical terms as the fundamental figure of speech and major form of figurative language, or trope. It has been analysed and approached in terms of its rhetorical constituent components (i.e. image, object, sense, etc.) and types (such as dead, recent, extended, compound, etc. metaphors). Now this approach no longer holds in the light of the latest developments of cognitive conceptual stylistic and ideological approaches to metaphor. Nowadays, metaphor has received yet greater attention from an entirely different perspective of conceptualization and ideologization. 
This paper attempts to investigate metaphor from a mainly cognitive stylistic perspective which views it basically as a matter of conceptualization of topics, objects and people in terms of certain ideologies. All metaphors are in principle reflections and constructions of concepts, attitudes, mentalities and ideologies on the part of the speaker. Hence, any metaphor is conceptualized in terms of target domain and source domain in different types of context and discourse, both literary and non-literary.

\section{Definitions: Conventional vs. Conceptual Approaches to Metaphor}

A new, enlightening trend in the approaches to the study of metaphor is already established now. A surge of tremendous work has been done to come out with many new explorations about conceptual metaphor. In the past twenty years or so, much has changed in the world of metaphor, which is no longer seen as "an ornamental aspect of language, but a fundamental scheme by which people conceptualize the world and their own activities" (Gibbs, ibid.: 3). Also, Semino (2008: 1) defines it as follows: "by metaphor, I mean the phenomenon whereby we talk and, potentially, think about something in terms of something else". Geary (2011) declares that metaphor "shapes the way we see the world".

Hence, the conventional approaches to metaphor that viewed it as an aesthetic and rhetorical formal structure of language in the first place are history now. Traditional works on metaphor were conducted within traditional disciplinary frameworks with the aim to locate it more as a part of language and culture than mind, and "a mere decorative device, simply involving the substitution of a literal term for a concept with a nonliteral one (Semino, 2008: 9). These approaches were unproductive. They failed to go through metaphor in depths and consider their conceptual implications and mental representations, and how they reconstruct our thoughts, attitudes and ideologies in a new, insightful way (see also Gibbs, 2008.: 5). By the same token, and in the light of recent approaches to metaphor, classifying metaphors traditionally into 'dead', 'fossilized', 'cliché', 'mixed, 'standard', etc. is not very useful, superficial and lacks in depth with regards to language analysis as much as translation. (For conventional types metaphor, see, for example, Newmark, 1988; Thornborrow and Wareing, 1998: 99-110; Leech 1969; Ghazala, 2011; Richards, 1936, in Wales, 1989/2001; and others. In contrast, the new types of conceptual metaphor are sharply insightful. Conceptual metaphoric studies pay due respect to all types of conceptual metaphor which are set in terms of conceptualization of the world.

\section{Types of Contemporary Conceptual Metaphor}

As argued above, the contemporary scholarship of conceptual metaphor has revolutionized the whole traditional literature about metaphor in language and style. Therefore, new types of metaphor are put forward in terms of cognitive conceptualization in the first place. Here is a crude account of major types of them:

1) Primary conceptual metaphors (i.e. Universal metaphors: e.g. PURPOSES ARE DESTINATIONS) (Kövecses, 2005 and $\mathrm{Yu}, 2008$ ).

2) Complex conceptual metaphors (cultural metaphors: e.g. A PURPOSEFUL LIFE IS A JOURNEY; ACTIONS ARE MOTIONS) (Gibbs, 1999, 2003; Kövecses, 2005 and Ning Yu, 2008, and Kintsch, 2008).

3) Complex (vs. simple) metaphor (e.g. THE WORLD IS A SMALL VILLAGE; THE UNIVERSE IS A COMPUTER) (see Kintsch, 2008)

4) Simple metaphors (e.g. SOME SURGEONS ARE BUTCHERS; MY LAWYER IS A SHARK (see ibid.).

5) Simple analogy based metaphor (e.g. SHE SHOT DOWN ALL MY ARGUMENTS) (see ibid.)

6) Novel / newly created conceptual metaphors (see ibid.)

7) Ideology-loaded conceptual metaphors (Semino, 2008: ch1 \& 3).

8) Ideology-free conceptual metaphors (e.g. 'emotion metaphors'. See also below) (Kövecses, 2008. See also Semino, 2008: 4.5).

9) Neutral conceptual metaphors (Driven et al: 2003, and Semino, 2008: ch. 1)

10)Culturally sensitive metaphors (and the notion of 'paradox of metaphor' (Gibbs, 2008: 5)

11) Master / superordinate metaphor (e.g. 'anger' and 'love' emotion metaphors) (Kövecses, 2008. See also Eliot's cat-fog metaphor above).

12)Dominant / central metaphors (see master metaphor above). 
13) Global metaphors (Cameron, in Semino, 2008: 34. See primary / universal metaphors above).

14)Ubiquitous / perverse metaphors (see Gibbs, 2008: 4; and Nogales, 1999: 3)).

15) Monomodal metaphor: either verbal, or nonverbal metaphor (see pictorial metaphor below. See Forceville, 2008)

16) Multimodal/complex concept metaphor (e.g. 'Remote control pad is Swiss army knife'. See ibid.)

17) Verbalized metaphor (contrasted with non-verbalized metaphor) (e.g. exchanging business cards is a knife duel'. See ibid.)

18) 'Meta-metaphor': a key metaphorical notion that functions as a backbone of a whole text e.g. 'a battle of metaphors' (as a title of an article indicating a series of related 'war metaphors'). See Semino, 2008: 32).

19) Vitalized metaphors: reconceptualised conventional metaphors (see 3 above, and Semino: ch. 1).

20)Recurrence metaphors: a series of related metaphors (Semino, 2008: ch. 1))

21) Master / superordinate metaphor (e.g. 'anger' and 'love' emotion metaphors) (Kövecses, 2008. See also Eliot's cat-fog metaphor above).

etc. (See especially, Gibbs, 2008; Semino, 2008; Steen, 2007; and Nogales, 1999 for further types and details).

Obviously, these types need further elaboration. However, they are intended here to stand for a sketchy representation of the complex reticulum of the new corpus of conceptual metaphor today rather than an exhaustive account of its new types. They are primarily deeply conceptual-based types (i.e. master, dominant, culturally sensitive, ideology-loaded, ideology-free, neutral, primary, universal metaphors). More specifically, conceptual metaphors are sets of 'mappings', across conceptual domains, whereby a 'target' domain ... is partly structured in terms of a different 'source' domain ..." (Lakoff and Johnson (1980b) (in ibid.: 5). The Target Domain (TD) is defined as the concept to be described by the metaphor; whereas the Source Domain (SD) is identified as the concept drawn upon, or used to create the metaphorical construction. Thus, in the metaphor MISERY IS A VACUUM, the target domain (TD) is MISERY, and the source domain (SD) is VACUUM.

Conceptual mappings of metaphor have recently resulted in great insights especially at the level of language. Further, according to Conceptual Metaphor Theory (CMT), metaphor enables us to talk and think about abstract, complex and/or poorly defined areas of experience in terms of concrete, simpler, physical and/or better defined areas of experience. This means that metaphor is a crucial linguistic and cognitive phenomenon (ibid.: 30) (see also Simpson, 2004). Hence the next point.

\section{A Cognitive Stylistic Perspective of Metaphor}

As pointed out earlier, the cognitive view of metaphor takes it not as a rhetorical by-product of objective thinking, but as the basis of the human conceptual system. Metaphors may be expressed in language accurately, for human thought processes are fundamentally metaphorical. There are a number of common expressions which demonstrate how metaphors structure our everyday concepts. This is a kind of metaphorical structuring, or conceptualization, of our thinking which is culturally and ideologically determined. Metaphors as such explain how we project our experiences with physical objects in the world on to non-physical experiences such as activities, ideas, emotions, feelings, etc., so as to be possible to refer, quantify and identify them; in short, 'to reason them out'. (For further argument, see Weber, 1995; Black, 2006; Lakoff and Johnson 1980; Lakoff 1987; and Lakoff and Turner (1989; and Cooper, 1986).

To Gibbs (1994), metaphor is not a distorted literal thought, but is a basic scheme by which human experience and the outside world are conceptualized. Therefore, Newmark's notion of metaphor as illusion, deception and a kind of a lie is dismissed in cognitive stylistics as irrelevant and untrue (1988: 104). We do not lie when we use metaphors; we make concepts and thoughts clearer and sharper. When, for example, in the Holy Koran (Chapter of Abraham: 24-26), the 'good word' (الكلمة الطيبة) is set in similitude to the 'good tree' (الثجرة الطيبة) whose roots are firm, and branches in Heaven, and gives its fruits every now and then by the will of its Lord. On the other hand, the 'evil word' "ألم تر كيف : is resembled to the 'evil tree' (الثجرة : الخلمة الخبيثة)

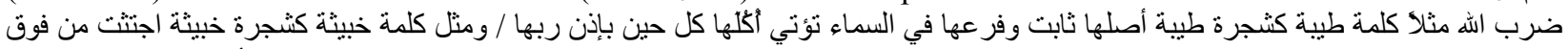
"الأرض ما لها من قرار. This exquisite similitude has not only clarified the concept of a 'good word', but extended it in an unprecedented way into a multi-productive concept of a uniquely 'good, fruitful, and heavenly tree', a completely 
different domain that has mapped, stretched, illustrated and encapsulated the conceptual domain of the 'good word'. The same argument applies to the second similitude of 'evil word' and 'evil tree'.

\section{Components of Conceptual Metaphor}

Cognitive theorists and stylisticians have identified metaphor, not as stereotyped types, but as a process of mapping between two different conceptual domains: the target domain (the concept to be described by the metaphor), and the source domain (the concept drawn upon, or used to create the metaphorical construction). Thus, in the statement: 'This room is an oven'. The target domain is our understanding of the concept of 'heat' for it is the concept we wish to express through the metaphor. The source domain for the metaphor may be conceptualized as 'an enclosed heated compartment / an extremely hot place' which is the vehicle for the metaphorical transfer. The whole metaphor can be represented by the following formula to abstract its underlying organization out of its particular linguistic structure: 'heat is an enclosed heated compartment'.

Notably, the relationship between metaphor and linguistic form is an indirect one, in the sense that the same metaphor can be conceptualized through more than one construction:

'This room is boiling (1).It is an oven. It is really hell in here (2). I mean

it is burning here(3). It is unbearable here(4). It goes to blazes(5).'

Generally, these five constructions can be seen as variations on the same metaphor, that of the same target domain (i.e. heat) and source domain (an extremely hot place/device/object) (see also Simpson, 2004).

\section{Originality of Conceptualized Metaphors}

The distinguishing feature that characterizes the study of metaphor in contemporary cognitive stylistics is originality in the different discourse genres, especially in political idiom and literary texts. An obvious way of realizing such originality of conceptualization is to suggest newly conceptualized metaphors that are unprecedented in language. Two examples can be cited by way of illustration, one from political idiom, another from literature. They are analysed cognitively in terms of the two domains of conceptualization suggested above. Then in a following stage, they are translated into Arabic and duly discussed.

\subsection{Realization of the Originality of Political Metaphor}

The following example is a set of statements borrowed from the political idiom used by pro-American British and American media sources to describe the unjustifiable American invasion of Iraq in 2003 (see Simpson, 2004: 42-43):

i. 'The third mechanised infantry are currently clearing up parts of the (sic.) Al-Mansour Saddam village area.'

ii. 'The regime is finished, but there remains some tidying up to do.'

iii. 'Official sources described it as a "mopping up" operation.'

These examples rehearse the same basic metaphor through three different linguistic structures. The target domain of the metaphor is 'the experience of war', whereas its source domain is 'the concept of cleaning'. Thus, the full formula of the metaphor can be presented as 'War is Cleaning'. The ideological re-conceptualization of 'war' introduced by this metaphor is quite clear. It suggests that the American atrocious invasion of Iraq is merely a conflict which is no more than a simple exercise in 'sanitation'. This point of view is inhuman and despicable for the Iraqis as well as any good human being in the world. Massacring innocent people is provocatively conceptualized in sanitary terminology. The ideological concept of the metaphor used by American and British press is an effort on their part to allay domestic anxieties about the invasion by playing down its terror through this outrageously motivated metaphor. To develop this point further, we may review some conventional, impartial conceptualizations of 'war' in such context of 'barbaric aggression':

$$
\begin{aligned}
& \text { - 'an all-out war'; } \\
& \text { - 'an atrocious war'; } \\
& \text { - 'a cruel war'; } \\
& \text { - 'a devastating war'; } \\
& \text { - 'a disastrous war'; }
\end{aligned}
$$




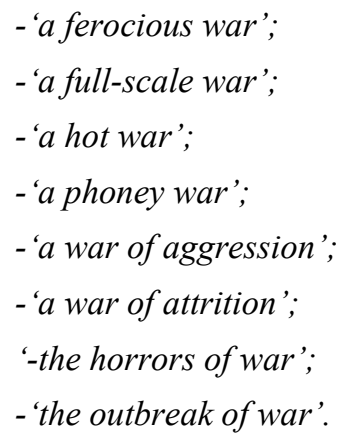

Thus, none of these expected conceptualizations of war relates in any way to 'cleaning', or its synonyms: 'clearing up', 'tidying up' and 'mopping up'. This new ideologized concept of war is bitter irony and preposterous forgery which aims at polishing the ugly face of the American war against Iraq. The argument is extended later in connection with the translation of these statements into Arabic.

\subsection{Realization of the Originality of Literary Metaphor}

The second example of realizing the originality of Metaphor is a literary passage of narrative (in ibid.: 145):

"Misery is a vacuum. A space without air, a suffocated dead place, the abode of the miserable. Misery is a tenement block, rooms like battery cages, sit over your own droppings, lie in your filth. Misery is a no-U-turns, no stopping road. Travel down it pushed by those behind, tripped by those in front. It happens so fast that once you get started, there's no anchor from the real world to slow you down.... Misery pulls away the brackets of life leaving you free to fall. Whatever your private hell, you'll find millions like it in Misery...." (Winterson: Written on the Body, 1993: 183)

The text is entirely metaphorical. It introduces a huge number of original conceptualized metaphors which might be unique. This uniqueness is featured out by having one target domain, MISERY, which is mentally represented by diverse source domains, as illustrated below:

$\underline{\text { Target Domain } \quad \text { Source Domain }}$

$\begin{array}{lll}\text { Misery } & \text { is } & \text { a vacuum } \\ \text { Misery } & \text { is } & \text { a space without air } \\ \text { Misery } & \text { is } & \text { a suffocated dead place; } \\ \text { Misery } & \text { is } & \text { the abode of the miserable; } \\ \text { Misery } & \text { is } & \text { a tenement block; } \\ \text { Misery } & \text { is } & \text { a no U-turns; } \\ \text { Misery } & \text { is } & \text { no stopping road; } \\ \text { Misery } & \text { pulls away the brackets of life leaving .... free to fall; } \\ \text { Misery } & \text { is } & \text { millions of hell. }\end{array}$

This target domain is so powerful that several source domains have been conceptualized out of it. Conceptualization has been presented mainly through concretization (all metaphors but the first two), and abstraction (the first two metaphors). Some of these source domains are based on terms of modernized life such as 'a tenement block' (building tower blocks / informal housing culture); 'no U-turns' / 'no stopping road) (traffic culture) and 'brackets of life' (fixing tools).

On the other hand, some metaphors have been conceptually elaborated through extension, making new concepts available for mapping. The metaphor, 'tenement blocks', for example, is extended by bringing into play individuated concepts within it, such as rooms. Rooms are conceptualized further as battery cages, or prison cells. Further metaphors can be chained, in the sense that a source domain from one metaphor may itself be opened up to form a target domain for a series of sub-metaphors that suggests new metaphorical mapping and conceptualization. The following examples are chained well in Winterson's text:

(1) Misery is a vacuum $\rightarrow A$ vacuum is a space without air $\rightarrow$ 
A space without air is a suffocated dead place $\rightarrow$ A suffocated dead place is the abode of the miserable.

(2) Misery is a tenement block $\rightarrow$ Rooms like battery cages $\rightarrow$

(In) battery cages you sit over your droppings, lie in your filth.

(3) Misery is a no-U-turns $\rightarrow$ No-U-turns have no stopping road $\rightarrow$

A road where you travel down ... in front $\rightarrow$ A road where you travel down it at a furious speed ... mummified in lead $\rightarrow$

A furious speed that happens so fast ... nothing to hold onto it.

So much for the cognitive view of metaphor in terms of conceptualization. Concentration will be now on the translation of metaphors basically as conceptualizations.

\section{Translating Metaphors Cognitively}

Unlike traditional approaches to the translation of metaphor in terms equivalence-non-equivalence in the Target Language (TL) for that of the SL, in a cognitive approach to translation, metaphor is understood as a cognitive process that conceptualizes people's minds and thoughts linguistically in similar or different ways in languages (see also Verdonk, 1999; Stockwell, 2002; Simpson, 2004; Boase-Beier, 2006; Maalej, 2008; Chakhachiro, 2011; and Ghazala, 2011). The contemporary mapping of conceptual metaphor into two conceptual domains, target and source, is adopted in the translation and discussion of the three illustrative examples used in the previous sections. The start is with the last example which is taken from the American military idiom, used as a kind of blackout on their army's atrocities in their invasion and then occupation of Iraq:

\subsection{Translation of Political Metaphor: e.g.}

(i) "'The third mechanised infantry are currently clearing up parts of the (sic.) Al-Mansour Saddam village area.'

$$
\text { (أ) تقوم فرقة المشاة المدر عة الثالثة بعملية توضيب أجز اء من منطقة قرية المنصور صدام }
$$

(ii)'The regime is finished, but there remains some tidying up to do.'

$$
\text { (ب) تم القضاء على نظام صدام، لكن بقي (علينا) القيام ببعض الترتيب '. }
$$

(iii)'Official sources described it as a 'mopping up' operation.'

$$
\text { (ج) وصفت مصادر رسمية العطلية بأنها عملية مسح }
$$

These statements rehearse the same basic metaphor through three different linguistic structures. The target domain of the metaphor is 'the experience of war', whereas its source domain is 'the concept of cleaning'. Thus, the full formula of the metaphor can be presented as 'War is Cleaning'. The ideological re-conceptualisation of 'war' introduced by this metaphor is ostentatiously clear. It suggests that the American unjustified, fabricated and atrocious invasion of Iraq is merely a conflict which is no more than a simple exercise in 'sanitation'. To develop this point further, we may review some conventional, collocational, impartial conceptualizations of 'war' in such context of 'naked aggression':

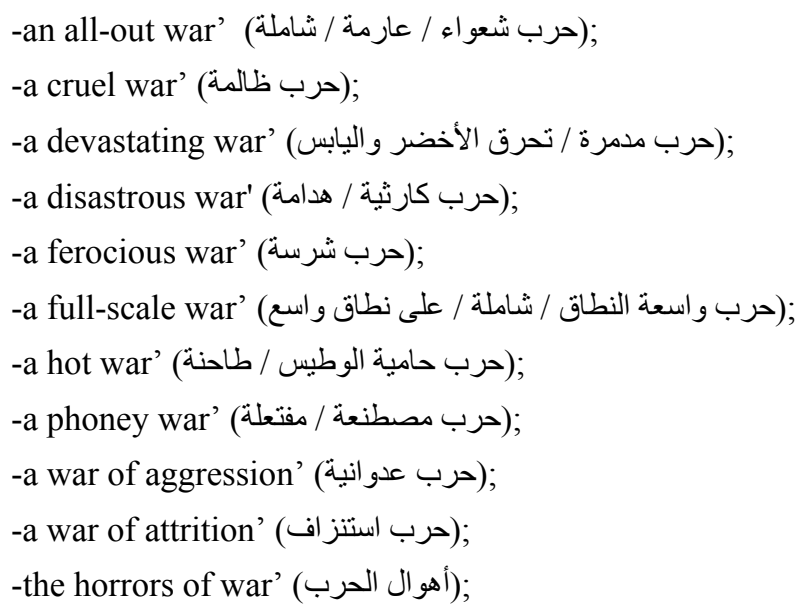


-the outbreak of war'(اندلاع / نشوب حرب).

Thus, none of these expected conceptualizations of war relates in any way to 'cleaning' (التنظف), or its synonyms: 'clearing up' (توضيب), 'tidying up' (ترتيب) and 'mopping up' (مسح). This new ideologized concept of war is bitter irony and preposterous forgery that aims at polishing the ugly face of the American war against Iraq. Therefore, another version of translation, which unearths the blacked-out truth of the normal domain 'War is Devastation' about this cruel war, is strongly favourable, especially for anti-American invasion of Iraq:

$$
\begin{aligned}
& \text { (أ) تقوم فرقة المشاة الددر عة الثالثة بعملية حرق الأخضر و اليابس لأجز اء من منطقة قرية المنصور } \\
& \text { (ب) نم القضاء على نظام صدام، لكن بقي (علينا) القيام ببعض عمليات الحرق و الإبادة الجماعية. }
\end{aligned}
$$

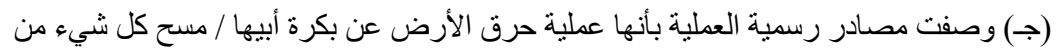

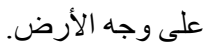

These translations unleash the mask on the real face of what really happened on the ground. The strongest possible terms and expressions to describe this vicious, inhuman war are used with the ideological and political aim to expose the realities about the aggressors before the whole world. Contrary to the first version of fake mitigation of the public through falsifying facts, this version has a provocative effect, instigating the public to condemn those aggressors through stating the truth about their war of aggression, which is the practice and ultimate objective of cognitive stylistic translation. Thus, although the first translation constructs the source text's masked concepts, the second constructs the hidden truth behind them. It is, therefore, left to readers to decide which translation to believe.

\subsection{Translation of Literary Metaphor}

The two examples, one narrative, another poetic, which are cited earlier are translated into Arabic cognitively and discussed in comparison with other versions:

(1)

The first literary example is the uniquely metaphorical narrative passage by Winterson (see also above). The translated part is reprinted here for convenience of reference. All metaphors are creative, novel and, hence, original. They centre round a sole target domain, namely Misery. It is an 'emotion metaphor' described by Kövecses (2008) as a 'master metaphor':

"Misery is a vacuum. A space without air, a suffocated dead place, the abode of the miserable. Misery is a tenement block, rooms like battery cages, sit over your own droppings, lie in your filth. Misery is a no-U-turns, no stopping road. Travel down it pushed by those behind, tripped by those in front..." (Winterson: Written on the Body, 1993: 183)

Due to the unusual significance of the style of literary texts like this one, and to the universality of Metaphor, the target translation has to be constructed in these terms of the source text, as follows:

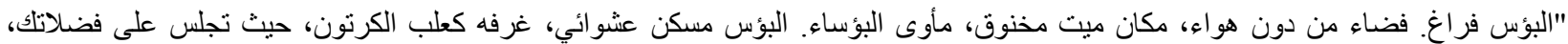

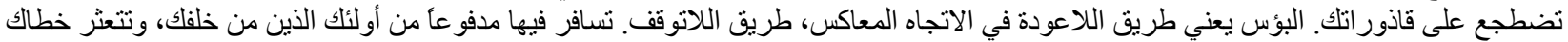

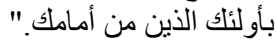

Obviously, the extract is wholly metaphorical. It introduces a great number of newly conceptualized metaphors that can be described as unique. This uniqueness is featured out by having one target domain, MISERY, which is mentally represented in a series of interrelated thread metaphors (described by Semino as 'recurrence metaphor' (2008: 23), and by Kövecses (2008) roughly as 'master metaphor') by different source domains. These domains are constructed in the Arabic translation in a similar way whenever possible, as illustrated in the following table (the Arabic domains are provided next to the English ones) (see the whole text in Simpson, 2004): 


\section{$\underline{\text { Target Domain } \quad \text { Source Domain }}$}

\begin{tabular}{|c|c|c|c|}
\hline Misery & is & فراغ a vacuum & 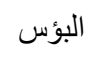 \\
\hline -Misery & is & فضاء من دون هواء a space without air & 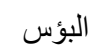 \\
\hline -Misery & is & مكان ميت مخنوق a suffocated dead place & 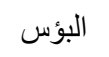 \\
\hline -Misery & is & the abode of the miserable مأوى البؤساء & 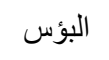 \\
\hline -Misery & is & a tenement block مسكن عشو ائي & 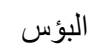 \\
\hline -Misery & is & a no U-turns طريق اللاعودة في الاتجاه المعاكس & 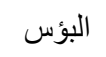 \\
\hline -Misery & is & طريق اللانوقف no stopping road & 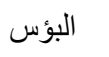 \\
\hline -Misery & pulls away & the brackets of life ... to fall يحل وثاق دعائم حياتاتك معلقً....لتقع & 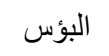 \\
\hline -Misery & is & ملايين من الجحيم millions of hell & البؤس \\
\hline Misery & is & كو ابيس ... تتحقق everyone's nightmares ... come true & الب \\
\hline
\end{tabular}

Conceptualization has been presented here mainly through concretization (all metaphors but the first two), and abstraction (the first two metaphors). Some of these source domains are based on terms of modernized life such as

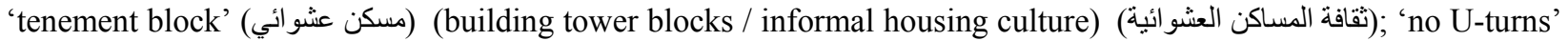

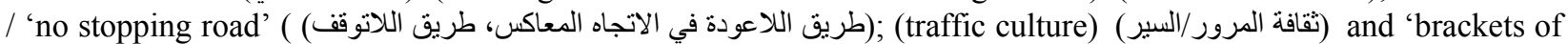

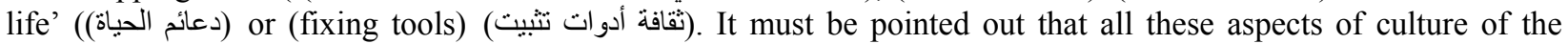
metaphor are universal now. In contemporary conceptual metaphor terms, they are universal metaphors.

On the other hand, some metaphors have been conceptually elaborated through extension, making new concepts available for mapping. The metaphor 'slums'/"ghettoes') أحياء الفقراء) is extended by bringing into play individuated concepts within it, such as 'rooms'. Rooms are conceptualized further as battery cages (علب كرنون), or prison cells. Being mostly universal, all these metaphors alongside their domains and sub-domains have been constructed in the target text in the same way (exceptions: علب كرنون (cartoon boxes) for 'battery cages' (literally: أقاص بطاريات); and (sealed in sealing/red wax) for 'mummified in lead' (literally: مختومة بالشمع الأحمر (s) (رحنة بالرصاص (a good choice might be رصاص مسكوب) (spilled lead)). The target translation, thus, seems as novel and original as the source text. Yet, following is another creative version of translation which preserves the target domain of the metaphor, MISERY, but constructs new source domains:

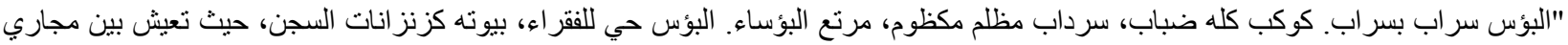

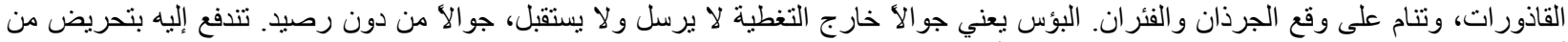

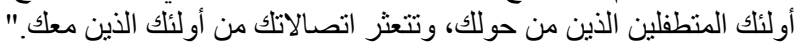

The source domains of this version are different in type of conceptualization, not in label. Similar to the source text labelling of the types of domains into general categorisation of concrete, abstract and so on, the target text has followed suit in this respect. Conceptualization has been presented here mainly through concretization (all metaphors but the first two), and abstraction (the first two metaphors). Some of these source domains are based on terms of modernized life such as 'a slum') (حي فقراء) (ghetto and informal housing culture) (تقافة الأحياء الفقيرة); 'a

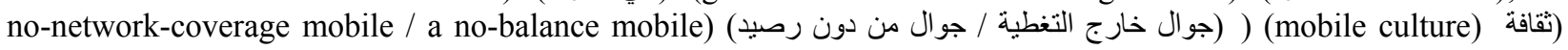
(الجوال; and 'heart pulse device' (تقاز نبض القبا) (today's medicine) (ثنب الطعاصر). The next table is a representation of the source domains in Arabic, translated back into English for convenience of illustration and comparison with those of the first version:

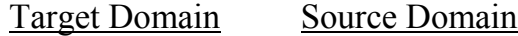

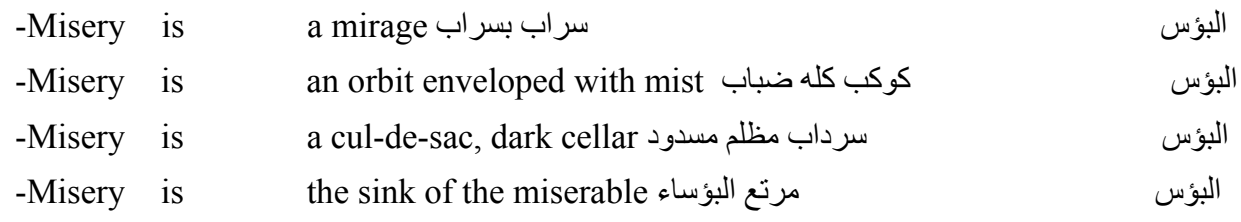




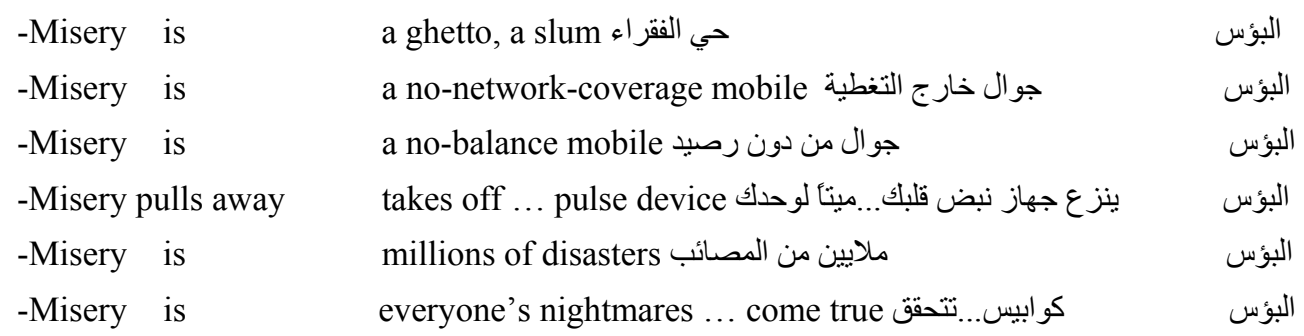

The two versions of translation suggested for the same source text are, to me, creative and novel. The way is wide open in such texts for translators to construct newly introduced metaphorical domains for the same metaphor.

(2)

The second example is poetic, extracted from Eliot's poem cited earlier (see above). Again the part which is translated is reproduced here for easiness of convenience:

The yellow fog that rubs its back upon the window-panes,

The yellow smoke that rubs its muzzle on the window-panes,

Licked its tongue into the corners of the evenings,

\section{Lingered upon the pools that stand in drains,}

(...)

(T.S. Eliot: The Love Song of J. Alfred Prufrock)

The first translation provided for these lines is an attempt to construct the same mental image of 'Fog' into metaphorical concepts and images in the target text, as follows:

$$
\begin{aligned}
& \text { الضباب الأصفر يحك ظهره على زجاج النو افذ، } \\
& \text { الدخان الأصفر يحك أنفه على زجاج النوافذ، }
\end{aligned}
$$

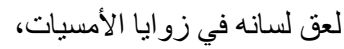

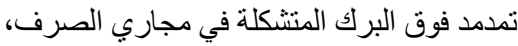

This version of translation has constructed and conceptualized the extensional master metaphor (i.e. FOG IS A CAT) and its sub-metaphors in the same way as in the source text (see also Semino, 2008, and Gibbs, 2008). The obvious reason is the novelty, originality and, hence, universality of these creative metaphors, in which case the translator into another language may optionally ignore the cultural factor, however temporarily. (For example, fog is usually not described as yellow in Arabic, only as 'thick' (كثيف), or tautologically as 'white' (أبيض). By so doing, the original metaphor of representing 'FOG' as a 'CAT' has been preserved and constructed in Arabic so that the same creative and brilliant conceptualization of the image of fog has been created for the target readers to learn and enjoy.

A prosodic improvement on this version of rhyme and rhythm in particular, which adds to the poetic speciality of the translation, may be suggested:

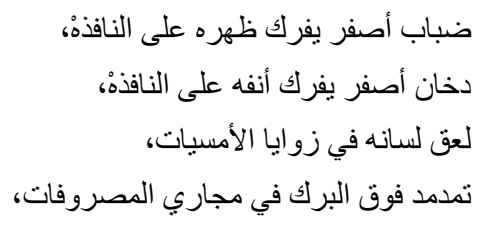

The originality and novelty of metaphors is not touched. However slight changes have been made to suggest a better poetic form of text in the target translation. For example, the plural form of 'windows' (نو افن) is replaced by a singular form (نافذه) with a stop (نكون) vocalization at the last sound to rhyme partly with most of the end sounds of the stanza. The same applies to the singular infinitive noun form of 'drain' (صرف) is substituted for the plural form with variation (مصروفات) to rhyme with أمسيات (evenings). Some deletions (cf. the first two lines), a change of word

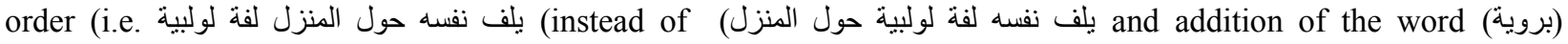
(quietly/slowly) at the end of the final line have been made for reasons of rhythm. 
Yet, a third version of a different approach which explicates metaphors might be possible in theory. Here is a suggestion:

$$
\begin{aligned}
& \text { الضباب الأصفر يغشي زجاج النافذة } \\
& \text { الدخان الأصفر يندي زجاج النافذة } \\
& \text { قبع في الزوايا في المساء } \\
& \text { انتشر بكثافة فوق البرك المتشكلة في مجاري الصرف الصفاء }
\end{aligned}
$$

\section{(Back Translation)}

("The yellow fog mists the window-panes,

The yellow smoke dews the window-panes,

Retracted in the corners of the evenings,

Spread thickly over the pools that stand in drains,")

This artificially assumed translation is a minimization of the original into a washed-out text that has lost all its creativity, originality and brilliance. It is a dull, literal explanation of the metaphorical expressions of the original. Translation is not precisely an explanation, for metaphorical conceptualization, especially in poetic texts, is the limestone of these texts. Explanation is in fact a kind of 'de-conceptualization', as it were, of them. Hence, this is a different version of a different text in of a different conceptualization that has distorted the originality and creativity of the original text by Eliot.

\section{The Study}

\subsection{Statement of the problem}

The fundamental question of this paper is the reconsideration of metaphor in contemporary terms of conceptualization from a cognitive stylistic perspective, and the possibilities of translating it into Arabic in similar terms. The trickiest problem of translating metaphor into Arabic on these bases could be how to achieve that convincingly in reality in theory and practice.

\subsection{Purpose of the Study}

The purpose of the study is twofold: First, to approach metaphor on contemporary conceptual cognitive stylistic grounds in accordance with the latest developments in conceptual metaphor studies; and, secondly, to put forward some suggestions and procedures for translating conceptual metaphor cognitively and stylistically into Arabic, with a background intention to unearth new pathways and explorations for approaching metaphor and its translation in contemporary cognitive stylistic terms.

\subsection{Procedure}

The major procedure used to present and achieve the aims and purposes of this research is a combination of corpus literature on conceptual metaphor and cognitive stylistics, followed by a practical application of that theory on the translation of metaphor cognitively and stylistically into Arabic. Confirmed practical evidence is provided through investigating the translation of three sets of English examples into Arabic to check to what extent theory is compatible with, and based on practice in translation.

\section{Discussion and Conclusions}

The previous discussion of the topic of this research has tackled translating metaphor in the light of contemporary developments of conceptual metaphor and cognitive stylistics. It has been introduced in two main parts, theoretical, and practical, to be later interrelated to provide evidence for the argument claimed earlier in the paper.

In conclusion, the paper has suggested a line of argument in favour of the conceptualization of metaphor in a cultural, political, ideological, social and mental environment. Such conceptualization has been claimed to crystallize the realities about people, concepts, objects, meanings and the whole world in general, and the relationships among them. Metaphor is no longer a mere rhetorical vehicle for adding an aesthetic flavour or power to meaning. In cognitive stylistics, it is a means of elaborating the writer / speaker's ideological and cultural concepts, meanings and perception of the world. 
The paper has also claimed that this cognitive stylistic perspective of metaphor has an influential impact on translation theory and practice. The way translators approach understanding metaphor as a conceptualization of things has to be reflected and constructed in the target language with this background of cultural, ideological, political, etc. conceptualization of the originality of metaphor. It is hoped that translation studies and practice take up this new turn in approaching the translation of metaphor cognitively. It helps explore new pathways and dimensions of meaning of texts in relation to one's culture, ideology, mentality, politics and community.

\section{Suggestions for Further Research}

The study proposed by this research can be developed in several other ways:

One way of doing it is to approach translation of metaphor in a contrastive study involving a comparison between a conventional and a contemporary approach to translating metaphors, and how (dis)similar the two approaches are, why and the conclusions from that.

Another way is to investigate the topic at the level of translating different types of text both ways between English and Arabic, with a view to drawing yet further evidence for a newly created theory of translating metaphor based on conceptual metaphor theory and cognitive stylistic theory.

A Third way of studying translating metaphor from a stylistic perspective is to consider the strong link between style and meaning in language and translation, alongside the latest cognitive approaches to style, including the novel approaches to the analysis and interpretation of metaphor in conceptual and ideological terms in particular. For assistance and further suggestions see in particular Simpson, 2004; Boase-Beier, 2006; Gibbs, 2008; Semino, 2008; Ghazala, 2011).

\section{References}

Black, E. (2006). Pragmatic Stylistics. Edinburgh University Press.

Boase-Beier, J. (2006). Stylistic Approaches to Translation. St. Jerome Publishing: Manchester, UK \& Kinderhook, USA).

Chakhachiro, R. (2011). Translating Irony: An Interdisciplinary Approach. Sayyab Books: London.

Cooper, D. (1986). Metaphor. Oxford: Blackwell.

Eliot, T. S. (1972). The Waste Land and Other Poems. Faber \& Faber: London.

Foreceville, C. (2008). Metaphor in pictures and multimodal representations. In Gibbs, R. (2008) (ed.), The Cambridge Handbook of Metaphor and Thought ( $2^{\text {nd }}$ edn. 2010) (pp. 462-482). Cambridge University Press.

Ghazala, H. (2011). Cognitive Stylistics and the Translator. Sayyab Books: London.

Gibbs, P. (2008). Metaphor and thought: The state of the art. In Gibbs, R. (2008) (ed.), The Cambridge Handbook of Metaphor and Thought ( $2^{\text {nd }}$ ed. 2010) (pp. 3-13). Cambridge University Press.

Gibbs, R. (1994). The Poetics of Mind: Figurative Thought, Language and Understanding. Cambridge: Cambridge University Press.

Kintsch, W. (2008). How the mind computes the meaning of metaphor: A simulation based on LSA. In Gibbs, R. (2008) (ed.), The Cambridge Handbook of Metaphor and Thought ( $2^{\text {nd }}$ ed. 2010) (pp. 129142). Cambridge University Press.

Kövecses, Z. (2008). Metaphor and emotion. In Gibbs, R. (2008) (ed.). The Cambridge Handbook of Metaphor and Thought ( $2^{\text {nd }}$ ed. 2010) (pp. 380-396). Cambridge University Press.

Lakoff, G. (1987). Women, Fire and Dangerous Things. Chicago: Chicago University Press.

Lakoff, G., \& Johnson, M. (1980). Metaphors We Live By. Chicago: Chicago University Press.

Lakoff, G., \& Turner, M. (1989). More Than Cool Reason. Chicago: Chicago University Press.

Leech, G. (1969). A Linguistic Guide to English Poetry. London: Longman.

Maalej, Z. (2008). Translating metaphor between unrelated cultures: A cognitive pragmatic perspective. STJ: London, pp. 60-82.

Newmark, P. (1988/1995). A Textbook of Translation. Prentice Hall: London. 
Nogales, P. (1999). Metaphorically Speaking. CSLI Publication. Stanford: California.

Richards, I. A. (1936). The Philosophy of Rhetoric. Oxford University Press.

Semino, E. (2008). Metaphor in Discourse. Cambridge University Press.

Simpson, P.(2004). Stylistics: A Resource Book for Students. Routledge: London \& New York.

Steen, G. (2007). Finding Metaphor in Grammar and Usage: A Methodological Analysis of Theory and Research. Amsterdam \& Philadelphia: Benjamins.

Stockwell, P. (2002a). Cognitive Poetics: An Introduction. Routledge: London \& New York.

Thornborrow, J., \& Wareing, S. (1998). Patterns in Language. Routledge: London.

Verdonk, P. (1999). The liberation of the icon: A brief survey from classical rhetoric to cognitive stylistics. Journal of Literary Studies, 15(3/4), 291-304. http://dx.doi.org/10.1080/02564719908530233

Wales, K. (1989/2001). A Dictionary, of Stylistics. Longman.

Winterson, J. (1993). Written on the Body. London: Vintage Books.

Yu, N. (2008). Metaphor from body and culture. In Gibbs, R. (2008) (ed.). The Cambridge Handbook of Metaphor and Thought ( $2^{\text {nd }}$ ed. 2010) (pp. 247-261). Cambridge University Press. 